\title{
The Impact of the Second National Fadama Development Project on Poverty Reduction in the Geidam Local Government of Yobe State, Nigeria
}

\author{
Bhola Khan ${ }^{1}$ \\ ${ }^{1}$ Department of Economics, Yobe State University, Damaturu, Nigeria
}

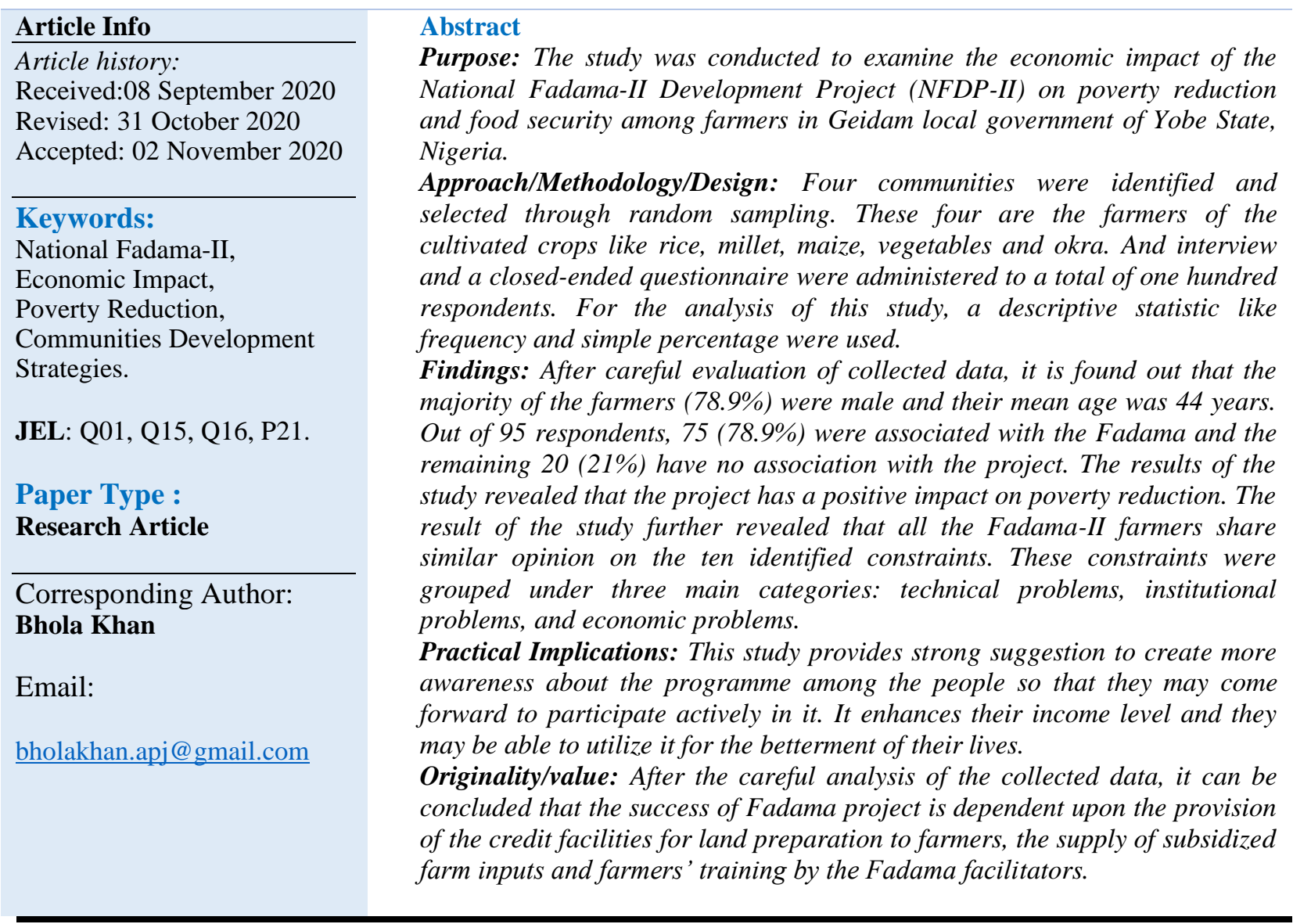

\section{Introduction}

The major challenges facing the developing countries such as Nigeria are food insecurity (insufficient food) and poverty (DFID, 2006). More than a billion people in the developing world live in the rural areas on less than a dollar per day, without enough money to buy food (Banerjee \& Duflo, 2011). It is estimated that of the 1.2 billion hungry and poor of the world, over 800 million suffer from chronic under-nourishment (Roser \& Ritchie, 2013). Out of this, 34 million live in Asia, while 186 million live in sub-Saharan Africa (DFID, 2006). Poverty is one of the gravest challenges facing the world today, with a staggering 40 per cent of the world's population living with the reality or the threat of extreme poverty, and one in five persons living in a state of poverty so abject that it threatens survival (Tokunbo, 2003). 
Globally, extreme poverty continues to be a rural phenomenon despite increasing urbanization (Anríquez \& Stamoulis, 2007). And out of the world's 1.2 billion extremely poor people, 75 percent live in rural areas and, they largely depend on agriculture, forestry, fisheries and related activities for survival (Tokunbo, 2003). Poverty in Nigeria has been described as "widespread and severe" (World Bank, 2015). The United Nations Development Programme (UNDP)'s Human Development Index (HDI) ranked Nigeria as the $137^{\text {th }}$ among the 174 countries listed with HDI of 0.384 in 1996 . By 1997 , the country slipped to $142^{\text {nd }}$ position and ranked among the 44 poorest countries. In 2018, Nigeria ranked number 158 out of 189 countries on the Global Human Development Index ${ }^{1}$. Nigeria's basic indicators now placed the country among the 26 poorest countries in the world. The proportion of Nigerians living below the poverty line of one dollar a day has increased dramatically during the last two decades. In the year 2018, about more than $65 \%$ of Nigerians were estimated to be living below the internationally defined poverty line. In the same year, in terms of GDP-PPP (in \$) Nigeria placed on 55 rank with 6,098\$ out of 191 countries (UNDP) ${ }^{2}$. About two-thirds of the Nigerian people are poor, despite living in a country with vast potential wealth (National Planning Commission, 2017).

The links between poverty and hunger are unambiguous, which means that poverty alleviation must play a major role in food security for all considerations (Franzet al., 2004). Food security is now defined as the situation when all people, at all times, have physical and economic access to sufficient, safe and nutritious food for a healthy and active life (FAO, 1996; Franz, et. al., 2004). However, this term has gone through stages of definition and redefinition. Approaches to its definition have ranged from an emphasis on self-sufficiency to an emphasis on coping with vulnerability and risk in food and nutrition access. In order to deal with the problems of food insecurity and high incidence of poverty among the rural poor in Nigeria, it is very imperative that agricultural productivity should be rejuvenated. It has been empirically established that low productivity in agriculture is the cause of high incidence of food insecurity and poverty in Nigeria (World Bank, 1996). It is therefore obvious that any policy measure aimed at alleviating poverty must take agriculture and rural development into consideration. Adeolu and Taiwo (2014) analyzed the poverty trend in Nigeria and noted that poor families are in higher proportion in farming households that are mainly in the rural area.

Previous and present governments in Nigeria have tried to sustain investment and support for agriculture by embarking on different agricultural and rural development programmes such as the National Accelerated Food Production Programme (NAFPP-1973), River Basin Development Authority (RBDA-1975),Operation Feed the Nation (OFN) in 1976, Agricultural Credit Guarantee Scheme (ACGS-1977), Green Revolution(GR-1980), Integrated Rural Development (IRD-1980), National Directorate for Employment (NDE-1980), Agricultural Development Programmes (ADP-1985), Directorate of Food, Roads and Rural Infrastructure (DFRRI-1987), the National Land Development Authority (NLDA-1992), The First National Fadama Development Project (FNFDP-1992), and the National Special Programme for Food Security (NSPFS-2003) (Ajayi, 2001; Daudu, 2008). These programmes were fashioned to

\footnotetext{
${ }^{1}$ (http://hdrstats.undp.org/en/countries/ profiles /NGA.html).

2 United Nations Development Programs Report, 2018.
} 
revolutionize the agricultural sector of Nigerian economy which was derailing from its normal contribution to the economy (Oriola, 2009).

The first National Fadama Development Programme (NFDP) was initiated to assist the qualifying states of the federation through the World Bank supported Agricultural Development Programmes (ADPs) network to, among others, finance the provision of shallow tube wells in Fadama lands for small scale irrigation, simplifying drilling technologies for shallow tube wells wash bores; constructing Fadama infrastructure; organizing Fadama farmers for irrigation management, cost recovery and better access to credit marketing and other services; and providing vehicle, pumps and other equipment. It is believed that the provision of this facility should not only boost agricultural production but enhance the income of the farmers and thereby lift them out of the vicious circle of poverty. The facility was enabled in the 1995/96 cropping year (Adeolu \& Taiwo 2004).

The FNFDP (Federal of Nigeria Fadama Development Project II) was initiated for small-scale irrigation development, to increase the productivity of the farming system during the dry and wet seasons (F.M.A.N.R, 1997; Agu, 2002; Nwalieji \& Ajayi, 2009). It was implemented in the seven core states of Bauchi, Gombe, Jigawa, Kano, Kebbi, Sokoto and Zamfara. All the other states participated as facilitating state, that is; states in which Fadama I activities were introduced on pilot basis. These states (five of the non-core Fadama (I) states, that is Borno, Katsina, Kogi, Kwara, and Plateau, and one of the Fadama I core states, (Jigawa) being cofunded by African Development Bank (ADB) have been selected for the funding support for the second phase of the project on the basis of a comprehensive set of criteria of: (i) a written proposed action plan for both upstream and downstream post-harvest activities, (ii) a written commitment for regular payment of counterpart funds deducted at source (at the Ministry of Finance), (iii) evidence of viable and active Fadama Resource User Groups or other economic groups, (iv) evidence of the existence of conflict management committees, (v) completion of a detailed assessment of existing Fadama infrastructure, and (vi) a record of Fadama (I) loan recovery rate of at least 75\% (ADF, 2003). As a follow up to the FNFDP, the World Bank and the ADB have jointly supported the Federal Government of Nigeria (FGN) to invest in a Second National Fadama Development Project (SNFDP) known as Fadama (II) project. The project (NFDP-II) targets the development of irrigation at small-scale, especially, in the low-lying alluvial floodplains or "Fadama". The NFDP-II is intended to increase the productivity, income, living standards and development capacity of the economically active rural communities while increasing efficiency in delivering implementation services to an estimated four million rural beneficiary households (Kudi, Usman, Akpoko and Banta, 2008; Nwalieji and Ajayi, 2008).

\section{Literature Review}

Fadama is the Hausa name for irrigable land and low-lying area underlined by shallow aquifers and found along Nigeria's river systems (Ingawa et al., 2004). Fadama also refers to a seasonally flooded area used for farming during the dry season. It is defined as alluvial, lowland formed by erosional and depositional actions of the rivers and streams (Qureshi, 1989). They encompass land and water resources that could easily be developed for irrigation agriculture (World Bank, 
1992). Fadama areas are considered to have high potential for economic development through appropriate investments in infrastructure, household assets and technical assistance. When Fadama spread out over a large area, they are often called 'Wetlands' (Usman et. al., 2008).

The theoretical framework for this study is based on programme evaluation models. Ajayi (2005) identified some of these programme evaluation models in agricultural extension to include: (i) Project participants and Non-project Participants model (ii) Reflective Evidence to Appraise Programme (REAP) model (iii) Effectiveness Model, (iv) Context Input Process and Product (CIPP) model, (v) Project Objectives, Project inputs, Project Outputs, Project Effect, Project Impact and Project Beneficiary (POIOEIB) Model.

The assertion of the World Bank (2015) that Nigeria is a paradox aptly captures the magnitude of the problem of poverty in Nigeria. By 1999, about 70 percent of Nigeria's population of about 120 million had income of less than $\$ 1$ a day and figures has risen since then (National Economic Empowerment Development Strategy (NEEDS, 2004). According to the United National Human Development Report (UNDP, 2018), Nigerian is ranked among the world's 20 (twenty) least developed countries. Out of 189, the UNDP (2018) ranked Nigeria 158th with a Human Development Index (HDI) value of 0.543. The report also put the Human Poverty Index (HPI, 2018), which measures human poverty as 38.8 percent, thus, classifying the Nigeria among 29th poorest countries of the world having ranked 75th out of the 103 countries for which the index has been calculated. The report also put the country's life expectancy at birth at 43.4 years. Mother and child malnutrition are prevalent with stunting and wasting symptoms manifesting among a lot of children in rural communities. Besides, data from Central Bank of Nigeria (CBN, 1999), Federal office of Statistics (FOS,2015), and National Planning Commission (NPC, 2017) indicate that while Nigeria's population has been growing at three percent per annum, that of food production has been increasing at only 1.5 percent per annum in the last five years. In fact, past agricultural estimates in Nigeria by various agencies show that the country's agricultural sector has performed below expectation and the Nigerian people can be said to be food in secured (Aneke, 2007).

Many scholars have pointed out that the high level of rural poverty in Nigeria is because of the neglect of agriculture by government. Nigeria agriculture suffer from a general problem of low productivity, poor production techniques, low investment, few intermediate inputs, low yields, infrastructural inadequacies, inadequate food supply and non-functional credit system (Yusuf, 1999). Food insecurity (absence of food security) is one of the most terrible manifestations of human deprivation and in inextricably linked to every other facet of the development predicament (Leisnger, 1998). Poverty is one of the major causes of food insecurity and sustainable progress in poverty alleviation is critical to improve access to food. Because deficits in food security stem from the combined effects of factors such as poverty, low level of food production, and diminishing environmental quality, the best way to deal with the challenge lies in strategies that tackle all problems comprehensively, that is transforming local agriculture into a sector that generates employment and income for rural people, stimulates the non- farm sector and the overall economy, and increase food supply (Leisinger, 998). 
Molnar and Aneke (2007) posits that food security is identified by lack of access to formal education, sustained cooperative endeavour; balanced family household; appropriately addressed gender and family roles; rampant poverty; appropriate social, political and economic discrimination; longer life expectances; enabling values and attitudes; and distribution of wealth. He concludes that "societies with low levels of social organization and week systems of human capital formation have high levels of food insecurity". Food security indicators are summary measures of one of the dimensions of food security used to demonstrate change or the result of a program activity for a target population. Indicator construction begins with a set of observations or measurements, of food security- related conditions at the level of the individual, the household, the community, the market or the region. Once the basic measurements have taken place, indicators are constructed by classifying individual observations according to a set of criteria (food secure/food insecure, malnourished/well-nourished), aggregating the individual observations to the level of program coverage and placing those observations in some programrelevant perspective (AED, 1999; FANTA, 1999; USAID, 1999 in Aneke, 2007).

In deciding which indicator or which measure should be included in a monitoring and evaluation system, several considerations like relevance, credibility, cost, comparability, time sensitivity and information use, should be kept in mind (AED, 1999; FANTA, 1999; USAID, 1999 in Aneke, 2007). Some food security indicators are difficult or expensive to measure directly. This is because the process of measurement is either time consuming and expensive as in the assessment of dietary intake; or they reflect complex processes as in the recording of total household income derived from a number of household members involved in diverse economic activities or total household expenditures.

The current study is delimited to Geidam local government Yobe State of Nigeria. It is a descriptive study and also makes use of validated questionnaire which is based on scientific twoscale point. In this study four communities have been selected and these communities are fully involved in Fadama activities such communities include: Gumsa, Ma'anna, Kusur, and Kelluri community. The objective of the study is to examine, via descriptive statistics, that the economic impact of FADAMA II among these communities on their livelihood and betterment of their life is feasible or not.

\section{Methodology and Procedures}

This research is based on descriptive analysis and it was chosen because it permits to carefully describe and explain the variables that exist in the study based on the data collected. The collected data was analyzed and presented as descriptive statistics in the form of tables.

The study used probability sampling method and it was based on descriptive survey making use of stratified sampling technique. The sample was drawn from the total population size of the four communities participating in FADAMA II. The total size of the population of the four communities is 990 and out of it, 100 participants were selected as a sample on the basis of proportional approach to stratification. The drawn sample is about 10 per cent of the universe. The data used for this study was collected using interview schedule for farmer with no formal education and the second part of method is through administer questionnaires for farmers that 
can read, understand and can also response to the questions contains in the questionnaires, both the interview schedule and the research questionnaires subjected to meet the research requirement, for data from the its original source.

Out of one hundred respondents, fifteen (15) was randomly selected and fifteen (15) questionnaires was distribute to them in order to clarify the questions items on the questionnaires and the questionnaires was given to five respondents for test before the final distribution to the total population of the respondents. After the final distribution of questionnaires, 95 were returned by the respondents.

\section{Results and Discussion}

This section deals with the data presentation and analysis of the respondents' socio-economic characteristics which includes the age of the respondents, sex, their marital status, respondents educational level, religions, occupation, forming/experience, membership, types of crop that the respondents farm, quantity of the crops getting in a year, poverty index, their feeding information and the constraints associated to the Fadama II users like high cost of food input, lack of sufficient land, lack of improved seed for planting, high cost of labour, high incidence of pests and disease, poor storage facilities, lack of credit facilities, level of poverty among Fadama II farmers low price of farm produce, lack of adequate technical knowhow and lastly their opinion about the National Fadama II Development project in their respective communities.

Table 1: Sex of the respondents

\begin{tabular}{lll}
\hline Sex & Frequency & Percent $\%$ \\
\hline Male & 75 & 78.9 \\
Female & 20 & 21.1 \\
Total & 95 & 100 \\
\hline
\end{tabular}

Source: Field Survey, 2019

The table above shows that $78.9 \%$ of the respondents are male and they constitute the greater percentage of the response, while 21.1 are female respondents. It shows that the females are having less interest in participating in the project. Therefore, it may be suggestive that local government should encourage more females to participate in such types of programmes.

Table 2: Age of the Respondent

\begin{tabular}{lll}
\hline Age & Frequency & Percent $\%$ \\
\hline $14-16$ & 5 & 5.3 \\
$17-19$ & 6 & 6.4 \\
$20-22$ & 17 & 17.8 \\
23And Above & 67 & 70.5 \\
Total & 95 & 100 \\
\hline Source: Field Survey, 2019
\end{tabular}

The above table 2 shows the age distribution of the respondents in four communities in Geidam local government. The 23 years and above respondents have the greater percentage of 70.5 , 
followed by respondents of the age between 20-22 years which have 17.8 percentage, then 17 19 years have 6.4 percent and for 14-16 age group having less participation in the programme.

Table 3: Marital Status

\begin{tabular}{lll}
\hline Marital Status & Frequency & Percent \% \\
\hline Married & 78 & 82.2 \\
Single & 17 & 17.8 \\
Total & 95 & 100 \\
\hline Source: Field Survey, 2019 &
\end{tabular}

From the table above, it is shown that the 70 respondents which constitute the 82.2 percent of the responses are married, while 17.8 percent are not married or single as shown in the table above.

Table 4: Educational Level of the Respondents

\begin{tabular}{lll}
\hline Education & Frequency & Percent $\%$ \\
\hline Primary & 3 & 3.2 \\
Secondary & 28 & 29.5 \\
Tertiary & 25 & 26.3 \\
No F. Education & 39 & 41.0 \\
Total & 95 & 100 \\
\hline
\end{tabular}

Source: Field Survey, 2019

The table shows that the majority of the respondents are those with no formal education which constitute the greater portion of the responses with 41.0 percent. Meanwhile, 29.5 percent of the respondents attended secondary school, and 26.3 of the respondents attended tertiary education. The smallest part of the respondents attended primary School with 3.2, percent.

Table 5: Religion of the Respondents.

\begin{tabular}{lll}
\hline Religion & Frequency & Percent \% \\
\hline Islam & 89 & 93.6 \\
Christianity & 6 & $6: 4$ \\
Total & 95 & 100 \\
\hline \multicolumn{2}{l}{ Source: Field } & Survey, 2019
\end{tabular}

The table above shows that the 93.6 percent of the respondents in the all four communities are Muslim, while the 6.4 percent of the respondents are Christian.

Table 6: Occupation of the Respondent

\begin{tabular}{lll}
\hline Occupation & Frequency & Percent \% \\
\hline Farmers & 48 & 50.5 \\
Businessmen/Women & 16 & 16.9 \\
Civil Servant & 18 & 18.9 \\
Others & 13 & 13.7 \\
Total & 95 & 100 \\
\hline
\end{tabular}

Source: Field Survey, 2019 
From the table above, it is clearly indicated that $50.5 \%$ of the respondents of the study communities were famers, and 18.9 percent are civil servants. As indicated, 16.9 percent are businessmen/women and $13.7 \%$ of the respondents are students and others.

Table 7: Farming Experience in years

\begin{tabular}{lll}
\hline Respondents Experience & Frequency & Percent \% \\
\hline 14-16 Years & 4 & 4.2 \\
$17-19$ Years & 10 & 10.5 \\
20-22 Years & 20 & 21.1 \\
23 And Above & 61 & 64.2 \\
\hline
\end{tabular}

Source: Field Survey, 2019

The above table shows that respondents with 23 and above years have the more farming experience than the other respondents. Those with the age of 20-22 years have the second largest proportion of the farming experience with $21.1 \%$, while the respondents that fall within the age of 17-19 years have farming experience with about $10.5 \%$. Lastly, the respondents with the age range between 14-16 years have the smallest proportion of the farming experience of $4.2 \%$

Table 8: Are you a member of Fadama II Association

\begin{tabular}{lll}
\hline Member & Frequency & Percent $\%$ \\
\hline Yes & 20 & 21.1 \\
No & 75 & 78.9 \\
Total & 95 & 100 \\
\hline \multicolumn{2}{l}{ Source: }
\end{tabular}

The table clearly shows that most of the Fadama farmers are not a member in National Fadama II program. In addition, $78.9 \%$ of the farmers do not know about the National Fadama II program which has its own member. As indicated in the table, $21.1 \%$ of the respondents are the members of National Fadama II development project.

Table 9: What Type of Crop do you grow?

\begin{tabular}{lll}
\hline Crop & Frequency & Percent \% \\
\hline Rice & 45 & 47.3 \\
Millet & 41 & 43.2 \\
Maize & 2 & 2.2 \\
Vegetable & 4 & 4.2 \\
Others & 3 & 3.1 \\
Total & 95 & 100 \\
\multicolumn{2}{l}{ Source: Field Survey, 2019 }
\end{tabular}

From the table above, it is shown that $47.3 \%$ of the respondents have rice farms and it constitutes the highest proportion of the respondents. Second to it, $43.2 \%$ of the respondents farm millet, $2.2 \%$ of the respondents cultivate maize, then $4.2 \%$ of the Fadama farmers farm vegetables and $3.1 \%$ of the respondents are farmers of other crop like Okra etc. 
Table 10: How many bags of crop did you get from your farm?

\begin{tabular}{lll}
\hline Bags Of & Frequency & Percent \% \\
\hline Rice & 360 & 47.3 \\
Millet & 329 & 43.2 \\
Maize & 16 & 2.2 \\
Vegetable & 32 & 4.2 \\
Others & 23 & 3.1 \\
Total & 760 & 100 \\
\hline
\end{tabular}

Source: Field Survey, 2019

This table shows that $47.3 \%$ of the respondents got about 360 bags of rice, $43.2 \%$ of respondents got 329 bags of millet, 16 bags of maize by the $2.2 \%$ of the respondents, $4.2 \%$ of Vegetable farmers got 32 basket and $3.1 \%$ of the respondents got 23 bags or baskets of the others crop.

Table 11: How many times does your family feed in a day?

\begin{tabular}{lll}
\hline Times & Frequency & Percent \% \\
\hline Once & 1 & 1.1 \\
Twice & 8 & 8.4 \\
Three Times & 80 & 84.2 \\
Others & 6 & 6.3 \\
Total & 95 & 100 \\
\hline Source: Field Survey, 2019
\end{tabular}

From the table above, it is shown that the majority of the respondents, that have the greater parts of about $84.2 \%$, eats three times in a day, while $8.4 \%$ of the respondents eats twice in a day. Meanwhile, $1.1 \%$ of the Fadama II farmers eats once in a day, but $6.3 \%$ of the respondents which participate in this questionnaire eats more than three times in a day.

Table 12: Does your family eats from your farm?

\begin{tabular}{lll}
\hline Sex & Frequency & Percent $\%$ \\
\hline Yes & 62 & 65.3 \\
No & 33 & 34.7 \\
Total & 95 & 100 \\
\hline
\end{tabular}

Source: Field Survey, 2019

The above table clearly shows that $65.3 \%$ of the National Fadama II development project participants eat from their farm's produce, while the $34.7 \%$ respondents indicated that they do not eat from what they farm.

\section{Constraints}

Do the following problems affect your participation in the National Fadama II Development project?

Table 13: Cost of Food Inputs

\begin{tabular}{lll}
\hline High Cost of Food Input & Frequency & Percent $\%$ \\
\hline
\end{tabular}




\begin{tabular}{lrl}
\hline Yes & 74 & 77.8 \\
No & 21 & 22.2 \\
Total & 95 & 100 \\
\hline & Source: Field Survey, 2019
\end{tabular}

Source: Field Survey, 2019

It was indicated from the survey that $77.8 \%$ of the respondents are affected by the constraint of high cost of food input, while $22.2 \%$ of the sample are not affected by the above constraints.

Table 14: Availability of Land

\begin{tabular}{lll}
\hline Lack Of Sufficient Land & Frequency & Percent \% \\
\hline Yes & 69 & 72.6 \\
No & 26 & 27.4 \\
Total & 95 & 100 \\
\hline
\end{tabular}

Source: Field Survey, 2019

The survey shows that the majority of the respondents are affected by the constraint of lack of sufficient land for planting.

Table 15: Availability of Seeds

\begin{tabular}{lll}
\hline Lack Of Improved Seed & Frequency & Percent $\%$ \\
\hline Yes & 80 & 84.2 \\
No & 15 & 15.8 \\
Total & 95 & 100 \\
\hline
\end{tabular}

Source: Field Survey, 2019

The table above shows that $84.2 \%$ of the respondents were affected by the constraints of lack of improved seed for planting, and $15.8 \%$ of the Fadama II users are not affected by the above constraints.

Table 16: Availability of Labour

\begin{tabular}{lll}
\hline High Cost Of Labour & Frequency & Percent \% \\
\hline Yes & 85 & 89.4 \\
No & 10 & 10.6 \\
Total & 95 & 100 \\
\hline
\end{tabular}

Source: Field Survey, 2019

The table above revealed that $89.4 \%$ are affected by the constraint of availably of labour, while $10.6 \%$ of the respondents were not affected by the above constraint.

Table 16: High Incidence of Pests \& Diseases

\begin{tabular}{lll}
\hline High Incidence of Pests \& Diseases & Frequency & Percent \% \\
\hline Yes & 67 & 70.5 \\
No & 28 & 29.5 \\
Total & 95 & 100 \\
\hline
\end{tabular}

Source: Field Survey, 2019 
According to the results in the table above, $70.5 \%$ of the respondents are greatly affected by the constraints of high incidence of pests and diseases. As shown, 29.5\% of the Fadama II users are not affected by the above constraints of high incidence of pests and diseases as the table showed.

Table 18: Poor Storage Facilities

\begin{tabular}{lll}
\hline Poor Storage Facilities & Frequency & Percent \% \\
\hline Yes & 59 & 62.2 \\
No & 36 & 37.8 \\
Total & 95 & 100 \\
\hline
\end{tabular}

Source: Field Survey, 2019

The statistics in the table above show that $62.2 \%$ of the respondents are affected by the constraints above, while $37.8 \%$ of the respondents are not affected by the constraint of poor storage.

Table 19: Lack of Credit Facilities

\begin{tabular}{lll}
\hline Lack Of Credit Facilities & Frequency & Percent \% \\
\hline Yes & 83 & 87.4 \\
No & 12 & 12.6 \\
Total & 95 & 100
\end{tabular}

Source: Field Survey, 2019

The table above shows that $87.4 \%$ of the respondents are affected by the constraints of credit facilities, while $12.6 \%$ of the respondents are not affected by the constraint associated to credit Facilities.

Table 20: Poverty Level of Farmers

\begin{tabular}{lll}
\hline Poverty Level Of Farmers & Frequency & Percent \% \\
\hline Yes & 87 & 91.5 \\
No & 8 & 8.5 \\
Total & 95 & 100 \\
\hline & Source: Field Survey, 2019 &
\end{tabular}

According to the above information on the table, $91.5 \%$ of the respondents are fully affected by the constraints of poverty in their participating National Fadama development project, while $8.5 \%$ of the respondents are not affected by the constraints associated to the poverty level of Fadama II farmers.

Table 21: Low Price of Farm Produce

\begin{tabular}{lll}
\hline Low Price Of Farm Produce & Frequency & Percent \% \\
\hline Yes & 63 & 66.4 \\
No & 32 & 33.6 \\
Total & 95 & 100 \\
\hline
\end{tabular}

Source: Field Survey, 2019 
The statistics in the table above reflect that $66.4 \%$ of the respondents are affected by constraints of low price of the farm produce. On the contrary, 33.6\% of the respondents are not affected by the constraints of low-price of the farm produce.

Table 22: Lack of Adequate Technical Know-How

\begin{tabular}{lll}
\hline Lack of Adequate Technical Know-How & Frequency & Percent \% \\
\hline Yes & 70 & 73.6 \\
No & 25 & 26.4 \\
Total & 95 & 100 \\
\hline
\end{tabular}

Source: Field Survey, 2019

The table above shows that $73.6 \%$ of the respondents are affected by the constraints of technical know-how, while $26.4 \%$ of the respondents as shown in the table above are not affected by the constraint of the technical know-how.

Table 23: What is your opinion on the National Fadama II development project on your community?

\begin{tabular}{lll}
\hline Opinion & Frequency & Percent \% \\
\hline Poverty Eradication Or Reduction & 60 & 63.2 \\
Need Credit From The Nfdp Ii & 10 & 10.5 \\
$\begin{array}{l}\text { Complain About The Services } \\
\text { Nfdp Ii }\end{array}$ & 10 & 10.5 \\
Not Re-Act To The Question & 7 & \\
$\begin{array}{l}\text { Appreciated The Program Nfdp Ii } \\
\text { No Clear Indication Of Opinion On }\end{array}$ & 5 & 7.4 \\
Nfdp Ii & & 5.3 \\
Total & 95 & 3.2 \\
\hline
\end{tabular}

Source: Field Survey, 2019

The survey shows that $63.2 \%$ of the respondent's opinion is to eradicate poverty from the Fadama Farmers. As indicated, $10.5 \%$ also shows that Fadama II farmers need credit from the NFDP II, another $10.5 \%$ of the respondents on the table above complain about the services delivery of the National Fadama II development project. As indicated, 7.4\% of the respondents do not care about the question, ignoring and giving no opinion. As the table depicts, $5.3 \%$ of the respondents shows their appreciation to the National Fadama II Development project on their services delivery, while $3.2 \%$ of the respondents could not form an opinion about the FADAMA Project.

\section{Results Discussion}

Table 1 implies that sex distribution of the farmers is skewed toward male in the Fadama II development project in Geidam Local Government. It revealed that most of the beneficiaries are male rather than female. Therefore, it is recommended that the local government should encourage the women participants in the future FADAMA activities. Table 2 implies that the 
majority of the respondents are within the middle age as well as active year of working. The data analysis in table 3 implies that more married farmers are involved in national Fadama II development project. It is also indicated that most of the Fadama II farmers are illiterate with greater percentage of $41.0 \%$. In addition, most of the Fadama farmers were Muslim and this implies that religion plays a greater role in Fadama farming.

The majority of the farmers were not employed by any government agency. The survey revealed that most of the respondents have been in farming system for quite a long time. In addition, the majority of the Fadama users are not a member of any Fadama II Association. As revealed in the data analysis, the majority of the farmers grow rice and this result implies that $47.3 \%$ of the farmers in Geidam Local Government deals with rice production.

Based on the responses, it is shown that 95 respondents get 760 bags of crop grown yearly, and this implies that a single respondent can get only 8 bags of the crop farmed. More importantly, most of the Fadama farmers in Geidam local government eat regularly three-time in a day from their produce. It is reflected that a number more than a half of the respondents eat from what they farm. From the above finding, it clearly indicated that the FADAMA II has a positive economic impact on the participants' livelihood and the betterment of their lives. Therefore, it is recommended that the state government as well as local government should encourage new farmers to participate in such kinds of programmes. An entire table of constraints revealed that all the constraints above directly or indirectly affect the farmers of the Fadama II in one way or the other. This implies that most of the farmers were associated with the constraints with about $77.5 \%$.

\section{Conclusion and Suggestion}

Based on the findings of the study, the socio-economic characteristics of the Fadama-farmers indicated that the majority of them were males with a long experience of farming and the majority of the respondents are within middle age. A common perception by Fadama-farmers on most of the identified problems shows that these problems affected the farmers directly or indirectly. The majority had no formal education and they are affected or associated with the agricultural constraints. Economic constraints and technical constraints still pose some problems in the area thereby slowing down the full implementation of the programme target,

Based on the major findings of this study, to improve the overall performance of the programme, the programme at all levels should ensure that the programme implementation plan, various LDPs are followed and the programme projects are completed. Given the fact that agricultural production operation is time-bound, it is recommended that the timely, adequate and consistent provision of farming inputs and Fadama facilities such as improved seeds, fertilizers, herbicides, tube-wells, rice dis-stoner etc. at subsidized cost by the NFDP(II) management should be provided. This will enhance the farmers' rice production in the area. The Fadama farmers should be encouraged by the provision of tractor services at subsidized rates, provision of training opportunities and by making the programme flexible to accommodate the peculiarities of the various locations. Employment of project facilitators should be specific to only those with good 
agricultural background especially in crop science and agricultural extension to allow effective relationship between the project and farmers. All participating communities should ensure that they have group leader who can serve as intermediate between the Fadama farmers and NFDPII implementers.

\section{Conflict of Interest}

The author of the article declares no conflict of interest.

\section{Funding}

This research study was not funded by any institution.

\section{References}

Adeolu, B.A. \& Taiwo, A. (2014). The Impact of national Fadama facility in alleviating rural poverty and enhancing agricultural development in south-western Nigeria. journal of social science, 9(3): pp. 157-161.

African Development Fund (ADF) (2012), A republic of Nigeria Fadama development project appraisal report agriculture.

African Development Fund (ADF) (2004), Fadama development project implementation manual. agricultural and rural development department OCAR.2.

Ajayi A. R. (2008) The role expectation of agricultural extension in poverty alleviation in a democratic and deregulated economy. In Eds. Agbamu J.U. Perspectives in agricultural extension and rural development, Pp 87-90.

Alawa, D.A. (2009). Agro-ecological degradation, poverty level and farmer education imperatives among smallholders' farmers in northern Cross River state Nigeria. An M.Sc. Thesis. Department of Vocational Teacher Education (Agric. Education), University of Nigeria, Nsukka.

Aneke, M. O. (2007). Impact of the phase-1 national special programme on food security on poverty reduction in Enugu state, Nigeria. An M Sc. Research finding presented to the Department of Agricultural Extension, University of Nigeria.

Anríquez, G., \& Stamoulis, K. (2007). Rural development and poverty reduction: is agriculture still the key?.Retrieved November 6, 2020, from http://www.fao.org/3/a-ah885e.pdf

Banerjee, A., \& Duflo, E. (2011). More than 1 billion people are hungry in the world. Foreign Policy, (186), 66-72.

Central Bank of Nigeria (CBN) research Department (1999). Nigeria's development, completion, implementation, coordination and monitoring, NAPEP compromises. Policy research bulletin, Vol.6, No.3, pp. 96-103, (May-July).

Central Bank of Nigeria (2010), Inflation rate online retrieved from www.cbn.com on the 14th October 2010.

Department for International Development (DFID) (2006) Millennium development goals: tackling poverty and hunger www.dfud.gov.uk. Pp 1-2.

Fadama Development office FDO (2006). Consolidated baseline study survey 
report of the six participating states.

FAO (2017) FAOSTAT. www.fao.org, Access December 2019.

FAO (2002) World food summit-five years later. http://www.fao.org/worldfoodsumit 30th June 2009

Franz, H., Achi, A. Hezron, N. Martine, P., Gérard, G. and Jean-Charles, L V., (2004). Development strategies and food and nutrition security in Africa: an assessment. international food policy research institute. December. pp 3-20.

International Organization Congress (1996)

Kudi, T. M., Usman, I., Akpoko, J.G and Banta, A.L (2008) Analysis of the impact of national Fadama development project ii (NFDP II) in alleviating poverty among farmers in giwa local government area of Kaduna state, Nigeria. In Ozean Journal of applied sciences 1(1). Ozean publications.

Leisinger, K.M. (1998). Biotechnology and food security. Paper presented at the interdisciplinary dialogue on Malthus and mender population, science and sustainable food security held at M.S. Swaminathan research foundation, Chennai, 28th January 1998.

National Fadama Objectives- Project Coordination Unit (PCU-NFDO, 2005).

National Planning Commission (NPC) (2017). National economic empowerment strategy: Abuja.

National Planning commission, (2015) National economic empowerment and development strategy (NEEDS) document. P xii.

National Population Commission (2006). Human population figures of 2006 census in Nigeria.

National Population Commission, (NPC) (2007). Population figure. Federal republic of Nigeria, Abuja. Retrieved from http://www.npc.gov

Oredipe et. al., (2004). Facilitators project implementation manual. Second national Fadama development project (Fadama II). Federal ministry of Agric and Rural Development. Abuja, Nigeria,

Qureshi, M. (1989). Water management in Fadama crops. A paper presented at the National workshop on Fadama and irrigation development in Nigeria held at Zaranda hotel, Bauchi, Nigeria.

Roser, M., \& Ritchie, H. (2013). Hunger and undernourishment. Our World in Data.

Tokunbo, S.O. (2003). Macroeconomic policies and pro-poor growth in Nigeria. Paper submitted for presentation at the world institute for development economic research (WIDER) conference on inequality, poverty and human well-being, Helsinki, Finland.

United Nations Development Programme (UNDP, 2018) Reports on Human Development Index, 2018.

World Bank (2015) Nigeria: Poverty in the midst of plenty; the challenges of growth with inclusion. A world Bank poverty assessment, population and human resources division report; No. 14733-UNI, Washington, D.C., the World Bank.

World Bank (2016) Second national Fadama Development Project: project appraisal document. at the annual national conference of Nigerian educational research association (NERA), University of Nigeria Nsukka, pp 1-20. 